Copyright () 2021 by Cherkas Global University

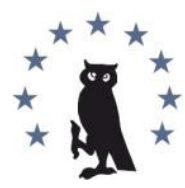

Published in theUSA

Propaganda in the World and Local Conflicts

Has been issued since 2014 .

E-ISSN 2500-3712

2021. 8(2): $70-80$

DOI: 10.13187/pwlc.2021.2.70

https://pwlc.cherkasgu.press

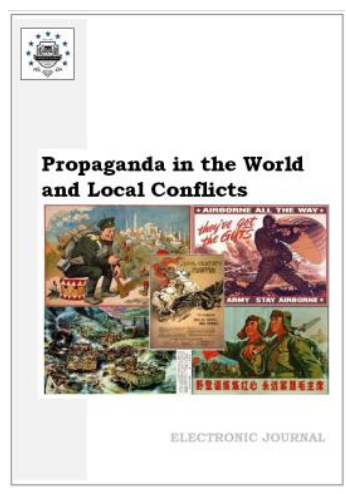

\title{
An Article by B.G. Plyushchevskii and Reminiscences by A.D. Sergeeva of the Trip Made by the Krasnaya Zvezda Agitation Steamer in Udmurtia during the Russian Civil War
}

\author{
Nikolay W. Mityukov ${ }^{\mathrm{a},{ }^{*}}$ \\ a Udmurt Federal Research Center of the Ural Branch of the Russian Academy of Sciences, \\ Russian Federation
}

\begin{abstract}
The paper publishes previously unprinted materials from the archival collection of the Center for Documentation of Contemporary History of the Udmurt Republic, which are dedicated to the Krasnaya Zvezda agitation steamer. The materials' chronological frame of reference is limited to July and August 1919, i.e. to the period when the ship was on the territory of modern Udmurtia. The first work is a scholarly article by Professor B.G. Plyushchevskii, written in the 1950s. The second one is comprised of two versions of A.D. Sergeeva's reminiscences of her meeting with N.K. Krupskaya on board the steamer, recorded apparently by V.Ya. Barinova in 1977 and stored in her archive.

As historical sources, both materials have limited value. B.G. Plyushchevskii's article delivers no conclusions but only cites truisms. For this reason, his work is more a synopsis rather than a comprehensive study. Similarly, A.D. Sergeeva's both versions predominantly use the published memoirs of N.K. Krupskaya as a basis. The work offers almost no original information.

Nevertheless, both materials can be instrumental in providing personal opinions of people, who lived in the 1950 s and 1970s, to uncover what they put their focus on in the first place. As they act within the confines of the existing ideology, they are impelled to repeat "the only correct viewpoint”. For example, B.G. Plyushchevskii's phrase that Kolchakites dug a mass grave of Red Guards soldiers in Votkinsk and burned the bodies, is given without any comments and communicates a noticeable negative shade of meaning. The Whites had to take this step out of necessity for sanitary reasons because the coffins were buried at such a shallow depth that spring melt waters completely washed out the burial. Similar ideological overtones, which had fully taken shape in the USSR by the time, can be perceived in assessments of other events mentioned. This explains quite logically why both materials have not been published so far.
\end{abstract}

Keywords: Krasnaya Zvezda agitation steamer, N.K. Krupskaya, Udmurtia, civil war.

\section{Introduction}

The Center for Documentation of Contemporary History of the Udmurt Republic, Izhevsk, Russian Federation, the former Party archive of the Udmurt Republican Committee of the Communist Party of the RSFSR, houses several archival collections of personal provenance. Two of them contain unpublished manuscripts about the Krasnaya Zvezda agitation steamer that operated in Udmurtia between July and August 1919.

\footnotetext{
${ }^{*}$ Corresponding author

E-mail addresses: nicoo2@mail.ru (N.W. Mityukov)
} 
The documents, which belonged to Boris G. Plyushchevskii (1912-1998), includes a manuscript "Activity of the Krasnaya Zvezda agitation steamer on the territory of Udmurtia in the summer of 1919" (CDNIUR. F. 4976. Op. 1. D. 45). From 1949, B.G. Plyushchevskii was a teacher in the Department of History of the USSR, Udmurt State Pedagogical Institute (now - Udmurt State University). In 1954, he presented his thesis for the Candidate Degree in Historical Sciences (at the A.A. Zhdanov Leningrad Order of Lenin State University) and in 1974 - for the Doctor Degree of Historical Sciences. The main corpus of his works addresses the question of peasants' situation, and for this reason the work on the trip of the Krasnaya Zvezda agitation steamer stands by itself. No confirmation of its actual publication was found. However, the list of B.G. Plyushchevskii's scholarly works, has a reference to the manuscript, which reads as follows: "Works not related to the topic of the dissertation: <...> 4. From the history of agitation and propaganda activities during the civil war and intervention (Activity of the Krasnaya Zvezda agitation steamer in the territory of Udmurtia in the summer of 1919). Izhevsk, 195_. 1 p[printed] sh[eet]." (CDNIUR. F. 4976. Op. 1. D. 18. L. 3).

The absence of exact imprint and year (it only indicates that this is the 50s) also verifies the opinion that the manuscript never went to press. In addition, with the gaps in the manuscript (to insert missing dates and bibliographic references), as well as question marks in pencil and underscored text, we can conclude that this is most likely just a draft of the manuscript, if nearly completed. The manuscript is typed on standard sheets of writing paper, there are no corrections in the manuscript, except for the underscored fragments and question marks mentioned.

The second manuscript is stored in the documents of personal provenance of Valentina Ya. Barinova (born June 12, 1940), former Head of the Department "History of the Bolshevik Organization of Izhevsk City" at the Udmurt Republican Museum of Local History. The manuscript is A.D. Sergeeva's reminiscences of the work of N.K. Krupskaya on the Krasnaya Zvezda agitation and instruction steamer in 1919. The file specifies no information about the memoirist, but makes it clear that it is quite an elderly teacher because the manuscript dates from 1977. The manuscript is typewritten sheets with multiple corrections in the text. The abstract to the file provides the date November 11, 1977 and says that there is no ending in the manuscript. However, a detailed analysis brings forward an assertion that the file comprises two versions of the same manuscript.

Both versions are typewritten on standard sheets of writing paper. Both versions have erased places (blotted out by the repeatedly typed letter "x") and inconsistent sentences. This suggests that both versions were created from dictation. Perhaps, when typing a later version, the memoirist had a typewritten earlier version available, to which they made changes during the dictation. The first version abounds with quotes from an unnamed work by N.K. Krupskaya, which suggests that the first version may be a kind of butt prepared before a meeting with the memoirist.

\section{Results and discussion \\ Plyushchevskii B.G. Activity of the Krasnaya Zvezda agitation steamer in the territory of Udmurtia in the summer of 1919}

During their fight against the allied intervention and counterrevolution, the Bolshevik Party and the Soviet government attributed critical importance to strengthening the connection between the center and regions. The peripheral Party and Soviet cadres needed support to correctly adopt the political line of the Communist Party in their efforts to roll out agitation and propaganda campaigns, activities in public education, culture development, health care and other measures. It was also crucial to introduce as flexible and varied forms of control as possible to enforce strict adherence to revolutionary legality at a local level. It was particularly imperative and urgent to address these challenges in the regions of the country where Soviet power was established for the first time or was re-established following a period of the White Guard rule.

In this context, it is interesting to review the activity of agitation trains (agitpoezd) and agitation steamers (agitparokhod), which contributed significantly into building up Party and Soviet efforts in regions in 1919-1920.

In the late 1918, the initiative of the Central Committee of the Russian Communist Party of the Bolsheviks (CC RCPb) created a detachment of literary agitation trains and steamers as part of the military department of the All-Russian Central Executive Committee (VTsIK) publishing house. In 1919-20, it operated 13 agitation trains and steamers. Journey plans were primarily developed to cover the areas recently liberated from White Guardists. Beginning in the late 1920, the literary 
agitation trains and steamers were renamed into agitation and instruction trains and steamers. In February 1921, they were transferred from the VTsIK's jurisdiction to Glavpolitprosvet (Main Political and Educational Committee of the Republic).

As the Russian Civil War and Allied Intervention ended, changes in the environment enabled a shift to other method of communication between the center and local organizations. In the second half of 1921, Party agitation trains and steamers (agitpartpoezds and agitpartparokhods, as they were termed at the time) stopped their operation except for the Oktyabr'skaya Revolyutsiya train, which made trips until the end of 1922.

This paper is an attempt to spotlight the activity of the Krasnaya Zvezda agitation steamer that visited Udmurtia in late July and early August 1919.

The work of the agitation steamer's team is featured in the article by Ts. Gofman "On the history of the Krasnaya Zvezda, VTsIK's first agitation steamer", but the author provides only a general description of the part of the trip that took place in Udmurtia (Voprosy istorii. 1948. 9). The book "Some questions of the history of the Udmurt ASSR" by M.A. Sadakov (Sadakov, 1960: 77-79) ${ }^{1}$ briefly focuses on the work of the Krasnaya Zvezda's agitation team in Udmurtia, which basically corresponds to the material in Ts. Gofman's article. Available archival materials give a possibility to have a closer look at the issue.

The Krasnaya Zvezda steamer (formerly known as the Anton Chekhov) was one of the agitation steamers in the Volga Kama flotilla. It made a long trip in the summer and autumn of 1919, with a significant portion of the route passing through Udmurtia that had recently been liberated from Kolchakite armed gangs. The steamer was accompanied by a barge assigned to it, which transported a motion picture projecting apparatus and a stock of propaganda literature with a capacity to store four cars of books, magazines, newspapers, leaflets, brochures and paintings. The agitation steamer team included representatives of some of the key people's commissariats, with the People's Commissariat of Education represented by N.K. Krupskaya. The agitation steamer carried on its activity through the following departments:

1) Political Department,

2) Information Department,

3) Instruction Department,

4) Complaints Office,

5) Board of Agitators,

6) Bureau of Rosta (Russian Telegraph Agency) and Radiotelegraph,

7) Book warehouse and bookstore,

8) Print Shop.

The planning of the agitation steamer's all aspects of operation and control over the activities of other departments were centrally delivered by the Political Department. The Political Department directly supervised the most important and politically relevant issues that arose in the process of scrutinizing the work of local bodies. The Instruction Department provided local Party and Soviet workers with guidelines on how to organize field activities - delineating scopes of responsibility, which were managed [the author's words - N.M.] by individual institutions, maintaining a reporting process, etc. The Information Department collected data related to the political and economic situation in the areas which were visited by the steamer. The work of the board of agitators was directed and reviewed by the Political Department on a systematic basis. After the work was completed in a particular destination, the Political Department called a meeting for agitators to share views and provide instructions on further activities. The Bureau of Rosta and Radiotelegraph issued a special bulletin designed to serve the local population, which was printed in the printing shop installed on the agitation steamer. The same printing shop also ran off leaflets written in simple and easy-to-understand language to explain a political and military situation as well as primary goals and specific activities of the Soviet government. The Complaints Office received written reports from the population and, if possible, immediately conducted on-the-spot investigations. Distributing printed propaganda and agitation materials was an essential part of the activities, which was done through a book warehouse and a bookstore.

\footnotetext{
${ }^{1}$ In this case, it seems logical to provide a reference to the entire book, but the author's work gives a reference to specific pages.
} 
The Krasnaya Zvezda's port of departure was Nizhny Novgorod, from which the steamer set off on 4 July 1919. The Krasnaya Zvezda arrived in Kazan on 10 July and began a new trip up the Kama River, to Perm inclusive, on 15 July. This period, i.e. from the end of July to the beginning of August 1919, when the team of the agitation steamer operated in Udmurtia, will be subject for review in the paper.

The visit of the Krasnaya Zvezda team to the territory, which now constitutes the Udmurt Autonomous Soviet Socialist Republic, lasted from 28 July to 5 August 1919. Udmurtia had been liberated from Kolchakite armed groups shortly before the events. The Red Army liberated Izhevsk [omission] July, Sarapul [omission] July, Votkinsk [omission] July, and Glazov [omission] July. The region's economy suffered colossal damage. A significant part of the population hid from the Whites in forests and returned to settlements very cautiously. Party and Soviet bodies in such trying circumstances embarked on the economic reconstruction and set up supply chains for the population, while serving the needs of the still close front. The agitation steamer leadership noted that the farther north the Krasnaya Zvezda traveled along the Kama River, the more striking were the defects in the work of the recently restored Party and Soviet apparatus and inefficiencies in agitation and propaganda activities.

Here are some facts that provide more dimension to the background in Udmurtia of the period. Despite the fact that the Kolchakite domination did not last long here, the injuries inflicted by White Guardists to the regional economy were disproportionately severe. The region's two largest manufacturing enterprises - Izhevsk and Votkinsk plants - lost most of their personnel and industrial equipment. The Izhevsk plant, immediately after the liberation, retained only $31.2 \%$ of its pre-war number of workers, and the Votkinsk plant $-21.5 \%$. The share of skilled workers dropped to $5 \%$ of the total personnel (TsGAOR ${ }^{1}$. F. 2351. Op. 1. D. 1. L.8, 2 i D. 7. L. 1-2). Kolchakite cut off drive belts, took away machine parts and demolished the power plant at the Votkinsk plant. They also transported a considerable part of equipment from the Izhevsk plant to Omsk. In addition, the rest of the equipment was sent away to the country's central regions when the Red Army evacuated Izhevsk and Votkinsk. Its prompt return was impossible, and it was delivered back to the plant administration step by step in the second half of 1919. Documentary evidence portrays horrific images of the White Guard terror, to which the population of Udmurtia fell victim in April and May 1919. In the Sarapul district alone, according to the Sarapul District Party Committee, the Whites tortured to death and shot down over 23 thousand people. Over 800 bodies were found outside Votkinsk. The Whites shot families of communists and everyone they suspected of being in sympathy with the Soviet government. They excruciated women, old people, teenagers and children. Coerced mobilization into the Kolchak army took place with thousands forcibly driven to Siberia during the retreat of the Whites. In Votkinsk, Kolchakite dug a mass grave of Red Guard soldiers and burned the bodies of the buried.

White Guardists also gravely impaired the republic's agriculture. Nevertheless, by the time of the Krasnaya Zvezda's trip through the Kama region, the working population of Udmurtia, led by Communists, had already achieved some successes in rebuilding the economic life in the region, and the efforts were, of course, prioritized so that to support the front. In the late June, the Izhevsk plant produced over 500 rifles per day ${ }^{2}$, and the day [shift] in the second half of July raised the output to 700 rifles (Izhevskaya pravda. 1919. 19 iyulya). In June-July 1919, the Votkinsk plant carried out repairs of various types of materiel and equipment for the Red Army, delivered 400 grates for the Volga-Kama warship flotilla, reconstructed and prepared vital shops, such as steam locomotive building and bridge building, for commissioning. The workforce at the Izhevsk plant amounted to 9 thousand people, and in Votkinsk - 6 [omission, the number is given in pencil] thousand, considering the fact that before the White Guard invasion in February 1919, the corresponding figures were -30 thousand $^{3}$ in Izhevsk and 8 [omission, the number is given in pencil] thousand in Votkinsk. The workers who had just experienced the atrocities of the Kolchakite regime, demonstrated considerable political enthusiasm. At a rally on July 8, 1919,

1 The Central State Archive of the October Revolution, from 1957 - the Central State Archive of the RSFSR (TsGA RSFSR), now - the State Archive of the Russian Federation (GARF). The reference to the archive makes it possible to identify that the article was written before 1957.

2 This line contains a question mark that was apparently put by a reviewer.

3 The number is underlined in pencil, the line opposite it has a question mark. 
Izhevsk workers resolved to maximize labor efficiency, refused to have weekends and holidays, and reduced their lunch break to a minimum (Izhevskaya pravda. 1919. 19 iyulya). Despite undermining activities by anti-Soviet groups, elections to local workers' councils were successfully held in Izhevsk and Votkinsk.

The middle peasant classes of the village showed an undoubted pivot to the Soviet power, resulted from the decisions by the 8th Congress of the RCP (b) on the attitude towards the peasant of medium welfare, as well as from the harrowing experience of the three-month Kolchakite rule. However, the influence of SRs, mainly of SR Maximalists, was still noticeable. Maximalists waged a brazen campaign of anti-Soviet slander and tried to disrupt the measures of the Soviet power. For example, in July 1919, i.e. quite shortly before the arrival of the Krasnaya Zvezda in Udmurtia, the Izhevsk Union of SR Maximalists resolved to employ any means to upset the elections to the local council, chanting the counter-revolutionary slogan: "Soviets without communists" (TsGAOR. F. 2351. Op. 1. d. 86. L. 1). Anti-Soviet agitation was also under way among workers at plants and among the rest of the population, designed to undermine workers' morale, criticize the Soviet government's policy on the food issue, etc. Against this background, the support, which could be provided by the leading workers and the agitation team of the Krasnaya Zvezda steamer to the local Party and Soviet bodies was of particular value and relevance.

As it continued its trip from Kazan to Perm up the Kama River, the Krasnaya Zvezda arrived in Karakulino on 25 July, in Kambarka on 27 July 1919, in Sarapul on 30 July. On 31 July, the steamer moored at a pier in Golyany ${ }^{1}$. Officials of the people's commissariats and the heads of the Krasnaya Zvezda political department left Golyany for Izhevsk and Votkinsk, and stayed in Izhevsk from 31 July to 2 August, and in Votkinsk from 3 to 5 August 1919.

Here is a list of activities carried out by the Krasnaya Zvezda personnel in Udmurt localities they visited.

The first settlement on the territory of the current Udmurt ASSR, included into the Krasnaya Zvezda's route, was Karakulino, a large village. The agitation steamer arrived here on 25 July. On the following day, representatives of the Krasnaya Zvezda's Political Department and members of the local Revolutionary Committee and the volost executive committee conducted a joint meeting, the evening saw a rally held with a report entitled: "Two powers". The number of attendees was up to 300 people. Afterward the Krasnaya Zvezda headed for Kambarka. In Kambarka, a factory village at the time with 3 or 4 thousand people living there, which was set up around a medium-sized metallurgical plant, the Krasnaya Zvezda team spent two days -27 and 28 July. On 27 July, in the afternoon, they examined the plant and held rallies in several shops. In the evening, a joint meeting was carried out with the Krasnaya Zvezda's political department and political and technical leaders of the Kambarka plant present. On 28 July, in the morning, instructors of the Krasnaya Zvezda's political department worked in the departments of the Kambarka Revolutionary Committee, where they became acquainted with the current situation and reports and carried out instructing sessions. At 4 p.m., a meeting of the political department instructors took place to finalize findings and results of the work done. At 5 p.[m.], a general plant rally was arranged, with a report on: "The political and military situation of the Soviet Republic and the objectives of the Soviet power". At 10 p.m. - a joint meeting by the Krasnaya Zvezda's political department and Kambarka Revolutionary Committee. The agitation steamer's book warehouse and bookstore worked in Kambarka with a great result as well. The warehouse distributed 4,395 printed publications (brochures and books), and the store - 314. Considering Kambarka's population, the figures clearly show that local residents felt a desperate craving for agitation and propaganda literature, for the Bolshevik printed word (TsGAOR. F. 2351. Op. 1. D. 18. L. 9).

On 29 July, the Krasnaya Zvezda was in Sarapul. Political Department instructors were put in the picture of the process set-up in the departments of the Sarapul Revolutionary Committee. A joint meeting was held with the Krasnaya Zvezda's Political Department and members of the Revolutionary Committee. On 30 July, N.K. Krupskaya delivered a speech at a meeting of Sarapul teachers. The event was attended by many educators from neighboring volosts, including those located to the east of the Kama. As an opening to the meeting, attendees sang the Internationale. In her speech, N.K. Krupskaya spoke about the outlook for public education, created by the Soviet Power, and highlighted the principles on which the new school was being built. With a passionate

${ }^{1}$ The author spells the name as "Galyany" throughout his article. 
appeal, she finished her speech urging everyone to support the Soviet Power that brought the light of enlightenment to the people. At first some of those present took a 'let's wait and see' attitude and were even wary, but then the audience's sentiment marked a turning point. Nadezhda Konstantinovna was seen off with enthusiastic applause and warm cheers. N.K. Krupskaya became acquainted with the situation of local teachers and asserted that the utmost would be done to ensure the normal operation of schools and alleviate the material burdens of teachers.

On 31 July, the Krasnaya Zvezda moored at the Golyany pier, where the shipbuilding shop of the Votkinsk plant was located ${ }^{1}$. Part of the agitation team remained in Golyany, and leaders of the Political Department went first to Izhevsk, and then to Votkinsk. In the Golyany village, the arranged an exhibition, which displayed posters, diagrams, paintings and literature available on the agitation steamer and its escort barge. The exhibition was attended by workers who worked at the Golyany pier and peasants from neighboring villages, in total over 400 people. The agitation steamer itself hosted a rally which presented a report on the political and military situation. The rally was very successful. In their reporting documents, the Krasnaya Zvezda board of agitators wrote that attendees expressed sentiments totally in favor of the Soviet Power (TsGAOR. F. 2351. Op. 1. D. 17. L. 7).

In Izhevsk, the event program was the following: 31 July - a joint meeting by the Krasnaya Zvezda Political Department and the Izhevsk Party Committee, City Executive Committee, General Plant Committee, representatives of the Metalworkers' Union and the plant's Political Committee. Following the meeting, a rally was held in the city garden in the evening on the topic: "Two powers". 1 August, in the morning, instructors of the Krasnaya Zvezda political department became acquainted with the work done by the departments of the Izhevsk District Committee and the City Council. In the afternoon, a rally was held at the plant on the topic: "Soviet power and the world socialist revolution". At 7 p. [m.], a rally was launched in the hall of the summer theater, dedicated to: "Nationalized industry and tasks of the working class". At 8: 30 p.m., another rally was held on the topic: "Two powers".

On 2 August, in the morning, instructors continued their work in the departments of the Izhevsk Revolutionary Committee and the City Council. At 5 p.m., the second joint meeting began held by the Krasnaya Zvezda Political Department and leading Party and Soviet bodies, which summarized the findings of the inspection carried out by instructors and gave instructions on the further steps to build up the work. At 7 p.m., a general meeting of the city party organization took place.

On 2 August, Izhevsk saw two more rallies: at 5 p.m. in Tatar in the Tatar quarter of the city, discussing: "Current moment", at 8 p.[m.] a rally in the city garden, discussing: "Where are workers and peasants lead to by the Soviet power".

On 3 August, officials of the Krasnaya Zvezda's Political Department and agitation team were already in Votkinsk. The general plant rally featured, among other speakers, N.K. Krupskaya, whose speech proceeded interrupted by rapturous prolonged applause that refused to quiet down. The instructors of the Krasnaya Zvezda's political department became acquainted with the work process in place in the Party and Soviet institutions in Votkinsk, and in the evening, officials of the agitation steamer's Political Department held a joint meeting with the Votkinsk Revolutionary Committee and the plant administration. On 6 August, the Krasnaya Zvezda continued its trip northwards along the Kama in the Perm direction, and on 7 August, made a stop and carried out a rally at the Galevo pier.

As the reporting documentation gives figures, characterizing the performance of the Krasnaya Zvezda team in the summer and autumn of 1919 , for the entire trip in general, it is impossible to sift out data related to the activities in Udmurtia. However, it follows from the above that the agitation steamer's team worked here in five locations - Kambarka, Sarapul, Golyany, Izhevsk and Votkinsk, with two of them (Izhevsk and Votkinsk) having a considerable proletarian population. Their work process was set up everywhere, based on one plan - becoming acquainted with the activities of local Party and Soviet bodies and with local Party, Soviet and trade union leaders. They commended achievements and pointed out at drawbacks in the activities by local bodies, heard their comments and requests and provided instructions on how to advance with the work in the future. They carried out rallies that attracted a large audience. All in all, 15 rallies were held - one in Karakulino, two in Kambarka, two in Sarapul, six in Izhevsk, one on the agitation steamer near the Golyany pier, two in Votkinsk and one in Galevo. The agitation team

${ }^{1}$ The shipbuilding shop of the Votkinsk plant was located in Galevo. 
noted the audience at the rally demonstrated high engagement: speeches were delivered one after another following the main report. Resolutions were passed reiterating the strong commitment to spare no pains to win the final victory over White Guardists. SR Maximalists made several attempts to take the floor at Izhevsk rallies, but their anti-Soviet demagogy provoked a negative reaction from attendees.

The work unmatched in scale and fruitfulness was done by N.K. Krupskaya. Her speeches in Sarapul, Izhevsk and Votkinsk brought forth an enthusiastic and sympathetic response from the audience. N.K. Krupskaya reminisces about her impressions received during the Krasnaya Zvezda trip in her "Memoirs of Lenin": "I shall never forget the meeting at the Votkinsk Works, where the Whites had shot almost all the teenagers. Never shall I forget the countless outrages and acts of violence which the peasants - mostly middle peasants - living around the Kama told us about" (Krupskaya, 1937: 39-40). The report of the agitation team of the Krasnaya Zvezda steamer reads: "Note should be made of the outstanding rallies at the Izhevsk Works, in Perm, Motovilikha, at the Votkinsk Works... Nadezhda Konstantinovna Krupskaya-Ul'yanov got particularly warm welcome at the rallies". N.K. Krupskaya spoke with great success in front of the teachers who came even from remote areas to listen to her ${ }^{1}$.

Analysis of the activities by the Krasnaya Zvezda Political Department and agitation team can identify several key lines in which they rolled out their work in the Kama region and, in particular, on the territory of Udmurtia. The first one was to provide help to rebuild industrial enterprises, badly damaged by the Kolchakite invasion, which played a major role in the country's economy and above all in meeting the needs of the front. After they had updated themselves to the existing situation, the leadership of the Krasnaya Zvezda Political Department, by sending urgent government telegrams, requested to dispatch experienced engineers and technicians to the Izhevsk plant, to assist the plant agents in purchasing critically scarce electrical accessories, as well as to return the evacuated equipment to Izhevsk and Votkinsk in the shortest possible time (TsGAOR. F. 2351. Op. 1. D. 17. L. 2).

Another challenging task was mobilizing food resources that the country's eastern regions could allocate to support starving proletarians in Moscow and Petrograd. In the summer and early autumn of 1919, the food crisis reached its worst. In July, Moscow's population received no bread at all for 10 days. Petrograd workers, who heroically repelled the onslaught of the Yudenich gangs, also struggled a desperate plight. It was necessary to establish facilities supplying food to the center in Udmurtia, just liberated from White Guardists. Meanwhile, local officials failed in some cases to pursue a sufficiently tough policy on the food issue. In Izhevsk, instead of three procurement categories, only two existed: the first one - workers, the second one - the rest of the population. Issue norms for the categories were higher than national ones. In June-July 1919, Izhevsk and Votkinsk had a practice of free trade in meat and vegetables in place, and senior Party and Soviet officials in Votkinsk justified this by alleging grain shortage and by the fact that liquidating the trade could, in their opinion, adversely affect political sentiments of the local people. The leadership of the Krasnaya Zvezda Political Department strongly commanded to correct the abnormalities and subordinate local interests to national ones.

The support, rendered to the local Party and Soviet apparatus, in building up political indoctrination was highly valuable. As mentioned above, SR Maximalists were still at work in Udmurtia in the summer of 1919. Assuming a mask of loyalty to the Soviet power, they orchestrated anti-Soviet falsehoods and tried to disrupt all the activities of the Party and Soviet government. Maximalists made efforts to run an anti-Soviet campaign in rural areas as well. It was all the more inappropriate that some of the local officials had poor knowledge of the decisions by the 8th Congress of the RCP (b), which took place in the second half of March 1919, in particular, of the Party's policy on middle peasants. The speeches, delivered by senior officers of the Krasnaya Zvezda Political Department before the officials of the local Party and Soviet apparatus, helped rectify the deficiency, and the rallies, which drew several hundred and sometimes more than a thousand attendees, played an important role in exposing Maximalists' anti-Soviet demagogy.

${ }^{1}$ The page has no footnote on it, but has a bibliographic reference (TsGAOR. F. 2351. Op. 1. D. 108. L. 2). 
In addition, the Krasnaya Zvezda team helped local Party and Soviet bodies to address a range of other issues.

Officials of the Political Department distinguished certain successes in restoring Party organizations in the Kama region liberated from the Whites. While there were only 5 communists in Izhevsk in the first days after the liberation, the number rose to more than 150 already by the beginning of August $1919^{1}$. However, the Political Department leadership emphasized the need to create a communist faction in the Metalworkers' Union in Izhevsk and Votkinsk. They also pointed out the insufficient outreach of the trade union among Izhevsk and Votkinsk workers (around 10$12 \%)$, and set the goal of one hundred percent worker engagement in the trade union.

The Krasnaya Zvezda's political workers and N.K. Krupskaya in the first place focused much attention on the situation in public education and health care in the areas in which the agitation steamer traveled. Interesting figures on the issues survived, outlining the situation in Udmurtia in the summer and autumn of 1919. At the end of July, i.e. only a month and a half after the Izhevsk liberation from White Guardists, the city already opened playgrounds for two thousand children, launched music classes and set up the work of a Proletkult sub-department. Two recreation center were opened for workers. The department of public education was comprised of three subdepartments - of school, preschool and extracurricular education. The situation with heating fuel for schools for the coming winter was bad. Teachers were paid at long intervals, which made many of them seek additional earnings. Local Party and Soviet bodies were suggested to allocate as big share from local resources as possible to help schools, and, at the same time, the steamer's Political Department reported to the People's Commissariat for Education about special attention needed for schools in the recently liberated areas.

The Krasnaya Zvezda Political Department required the Party and Soviet organizations to take special care of the families of Red Army soldiers, who were at the front, and to the families of those killed for the Soviet power. As a serious shortcoming in their work, it was pointed out that such families were not even registered in many localities in July 1919. The families of Red Army soldiers, as Political Department leaders clarified, were subject to tax exemption, they were to be provided with support in cultivating land if the family did not have able-bodied members.

The instructions by the Political Department pointed out that there was no a clear functional differentiation between local bodies. Many officials had no precise understanding what they were responsible for and what entitled to. The lack of experience had its impact, and, moreover, the corresponding instructions from the center failed to reach the local level. For example, the Sarapul District Military Commissariat extended, at its discretion, leave certificates of the Red Army front soldiers who were on vacation. The book warehouse and bookstore of the agitation steamer provided local Party and Soviet officials with many works of political literature and materials from the 8th Congress of the $\mathrm{RCP}(\mathrm{b})$ in the first place, as well as with guidelines and references required for their day-to-day work. As a side note, the bookstore and warehouse distributed propaganda brochures in numbers among the population, for example, A. Dickstein's ${ }^{2}$ "What do people live by", revolution fiction, for example, works by M. Gorky, fables by Demyan Bedny and others.

Izhevsk's Revolutionary Committee and the Executive Committee requested the Krasnaya Zvezda's Political Department to support their petition to isolate Izhevsk and 18 adjacent volosts into an independent administrative unit. A similar petition was set in motion by the Revolutionary Committee and the Executive Committee in Votkinsk in respect to Votkinsk with its adjacent volosts. With a comment that the issue required careful consideration, the Political Department leadership expressed no final judgment (Arkhiv Votkinskogo zavoda3. F. 785. Op. 1. D. 73. L. 6). The administrative territorial reorganization was not implemented in the period of the Civil War and Intervention ${ }^{4}$.

\footnotetext{
${ }^{1}$ Numbers 5 and 150 are underlined in pencil, and a question mark is put on the margin opposite them.

${ }^{2}$ This refers to Shimon Dickstein (1858-1884), a Polish biologist and publicist, translator of Karl Marx's "Capital" into Polish, author of the brochure "What do people live by" (Kto z czego żyje?), popular among socialists and reproduced in Russia in great quantities.

3 The author's works, this refers to the Votkinsk Plant archive in the modern Central State Archive of the Udmurt Republic.

4 The sentence is underlined in pencil with a question mark opposite it.
} 
Certainly, the above matters were secondary to measures aimed to revive industrial enterprises in the Kama region, mobilize food supplies to support the center and building up the fight against SR Maximalists.

The trip by the Krasnaya Zvezda agitation steamer, which V.I. Lenin set a high value to, played a major role in cementing the connection between the center and localities and in improving the work of all links within the Party and Soviet apparatus (Krupskaya, 1937). This conclusion is amply demonstrated by the facts, relating to the activities by the Krasnaya Zvezda team in Udmurtia.

\section{A.D. Sergeeva [The title is written in hand, illegible] 11.11.77}

In the summer of 1919, an initiative by V.I. Lenin sent VTsIK's agitation and instruction steamer Krasnaya Zvezda to the areas along the Volga and Kama Rivers, liberated from the White Army. The boat carried representatives of the CC of the Party, VTsIK and Sovnarkom (Council of People's Commissars), among them was N.K. Krupskaya.

From 27 July to 3 August, the Krasnaya Zvezda agitation steamer traveled across Udmurtia. The participants of the trip visited Kambarka, Sarapul, Galevo and Votkinsk in this period. They became acquainted with the activity of local Party, Komsomol and trade union organizations and helped them set up the work. N.K. Krupskaya devoted much attention to public education with a deep look into the activities of public education departments and schools.

N.K. Krupskaya kept a journal during the trip ${ }^{1}$. Here are some excerpts from Krupskaya's journal of the trip: "Last year (1919), I had to work for 1 1/2 months as an instructor of the People's Commissariat for Education on the Krasnaya Zvezda steamer. I made a journey from Nizhny Novgorod to Kazan along the Volga and to Perm along the Kama. We sailed only at nights and in the daytime stopped in cities, villages, at factories, in suburbs...

I was lucky to work in the best possible conditions, together with a group of about 20 fellow instructors and agitators, with whom we discussed everything we saw after each stop and jointly developed a plan for further work. Thanks to this, we succeeded in implementing a relatively large organizational work, and this turned out to be of special relevance for areas which only recently had been occupied by the Whites and where efforts were made to set up the work anew.

For a report to my commissariat and for myself, I kept a "Journal" for the entire 1,5 months, excerpts from which I am citing” (N.K. Krupskaya).

N.K. Krupskaya's travel journal reflects the style she worked in. In addition to speeches at rallies, N.K. held endless conversations. All and sundry were eager to talk with N.K. Krupskaya. These were Party and Soviet heads, peasants, workers, teachers and lots of women.

The boat was also visited by Azin, the legendary division commander, who had liberated Izhevsk from the Kolchakite.

N.K. writes in her journal: "In the evening, Azin, whose name is resounding throughout the Ural region, came to see me on the boat".

It should not go unspoken what a cordial, what a comprehensive, what a thorough approach did N.K. adopted in her conversations on public education with teachers and women. "Izhevsk and Votkinsk suffered the horrors of White Guardists and Kolchakites. And when at one of the meetings women told us about what had just happened in these parts, when there were victims in every family, when it was a rare family that sustained no loss at the hands of the Whites. And when they suddenly burst into song 'You fell victim', sobs broke out”, N.K. writes

Understandably, with deep sympathy and compassion did N.K. perceive the grief experienced in the fight against White Guardists. "At this meeting, when this feeling of anguish rose to such force that the audience sang 'You fell victim', sobs broke out", N.K. writes in her journal.

It was then when I first realized how close N.K. was to the people, how close and dear the school, the education of the people was to her, how deep her concern was for children our younger generation. What bitterness she endured when she was told how many teachers had gone with White Guardists. N.K. described how Lenin spoke about the role of the teacher in the

\footnotetext{
${ }^{1}$ The work constantly refers to an unnamed journal of N.K. Krupskaya. Perhaps the author means a journal published under the title "Through the cities and villages of the Soviet Republic" (Po gorodam i vesyam Sovetskoy respubliki) in the Novy Mir journal in 1960.
} 
socialist so[cie]ty: "One must not confine oneself to narrow pedagogical duties", that "teachers must join forces with the entire body of the embattled working people", that "the task of the new pedagogics is to link up teaching activities with the socialist organization of society".

How opportune and insightful this Leninist thought, expressed by N.K. in those circumstances, is. She writes in her journal how one teacher said that they, the teachers, now understood what a labor school was.

For me, this interaction with N.K. was a crucial event.

\section{A.D. Sergeeva N.K. Krupskaya - my teacher [A handwritten note: "In the Motherland"]} 19.11.77

I first saw N.K. in my Motherland, in Udmurtia, when she traveled on the Krasnaya Zvezda steamer as part of the activist group of prominent propagandists, and N.K., in the humble position of public education instructor, was included [in it], as ordered by the CC and advised by V.I. The Krasnaya Zvezda steamer sailed through the areas from which White Guardist hordes, who had committed appalling crimes of mass terror, had just [been] driven out. The people lived through inerasably horrible days. Mass shootings were perpetrated in prisons, [people] were imprisoned in sheds, on barges, starved to death, barges were drowned in the Kama. The wounds still bled, a rare family sustained no grief.

The propagandists on the Krasnaya Zvezda steamer worked tirelessly, speaking at meetings and rallies. Workers, peasants and teachers came to the boat.

N.K. writes in her journal that Azin, the legendary division commander, who has liberated Izhevsk from Kolchakites, came. Everyone was anxious to hear revolutionary words coming from Moscow, from the center, a word from Lenin.

What rallies, what meetings these were. How vital this revolutionary word was, convincing, calling for struggle. A word that heals wounds, unites, urges for the fight against counterrevolution. And there were these words. They were needed for the people. And the people heard them. The agitators heard the words of willingness from the people to continue the fight, no matter how hard it was. To fight did the speeches of the agitators and Red Army soldiers unfalteringly encourage. The call for fight was consonant with the people. The oath of allegiance to the revolution was sworn in the words of the workers and peasants. Unity with the agitators also gave rise to deep feelings of the loss of their comrades, relatives, loved ones and children.

N.K. writes in her journal how thousands of people at a rally sang "You fell victims in a fatal battle of selfless love for the people..." weeping with unbearable sorrow and pain, with those overly excruciating sufferings for the fighters who died for the people's cause.

N.K. writes in her journal about a meeting with teachers with whom she had a conversation. There were about a hundred of them. And the meeting saw the same thing as the rally. Without the slightest preparation, the teachers began singing during the conversation: "You fell victims in a fatal battle..."

This was an expression of the lofty sentiments and love for the people, for the cause of the revolution and for the fighters fallen in a fierce battle with Kolchakites.

It was then that I saw and comprehended N.K., her strength, her revolutionary spirit, her deep love for the people. And I remember what I felt: Here she is, a great, noble, staunch revolutionary. And the feeling still lives inside me - a feeling of respect, recognition, gratitude. I am committed to her pedagogical ideas. Wherever I work in in public education, I am guided by N.K.'s pedagogical thoughts.

\section{Conclusion}

The works under review - a scholarly article by Professor B.G. Plyushchevskii and two articles in the personal reminiscence style by A.D. Sergeeva - have a rather limited value as historical sources. B.G. Plyushchevskii's article delivers no conclusions but only cites platitudes. Therefore, his work can only be considered as a synopsis. Similarly, A.D. Sergeeva's articles predominantly quotes information borrowed from N.K. Krupskaya's reminiscences. It offers almost no its own original details. 
Nevertheless, both materials can be instrumental in providing personal opinions of people, who lived in the 1950 s and 1970s, to uncover what they put their focus on in the first place. As they exist inside the existing ideology, they are impelled, echoing already printed works, to repeat "the only correct viewpoint". For example, B.G. Plyushchevskii's phrase that Kolchakites dug a mass grave of Red Guards soldiers in Votkinsk and burned the bodies, is given without any comments and as a result carries a noticeable negative connotation. The Whites had to take this step out of necessity for sanitary reasons because the grave was so shallow that spring melt waters completely washed out the burial. Similar ideological overtones, which had fully taken shape in the USSR by the time, can be perceived in assessments of other events mentioned. This explains quite logically why both materials have not come to press up to this day.

\section{References}

Arkhiv Votkinskogo zavoda - Arkhiv Votkinskogo zavoda [Archive of the Votkinsk plant].

CDNIUR - Tsentr dokumentatsii noveishei istorii Udmurtskoi Respubliki [Center for Documentation of the Contemporary History of the Udmurt Republic].

Izhevskaya pravda - Izhevskaya pravda. 1919. 19 iyulya.

Krupskaya, 1937 - Krupskaya, N.K. (1937). Vospominaniya o Lenine [Memories of Lenin]. Bol'shevik. 2. [in Russian]

Sadakov, 1960 - Sadakov, M.A. (1960). Nekotorye voprosy istorii Udmurtskoi ASSR [Some questions of the history of the Udmurt ASSR]. Izhevsk. Pp. 77-79. [in Russian]

TGAOR - Tsentral'nyi gosudarstvennyi arkhiv Oktyabr'skoi revolyutsii [Central State Archives of the October Revolution].

Voprosy istorii - Voprosy istorii. 1948. 9. 